\title{
Modelling of Batang Rejang for Extreme Events
}

\author{
D.Y.S. Mah, N.C. Nam, F.J. Putuhena and P.L. Law
}

\begin{abstract}
Flood is a natural hazard. It happens when the water in a river channel is beyond the capacity of the channel to carry while the overflowing water is called as floodwater. Flood causes damage to life and property when it strikes a vulnerable population in the affected area. There are several townships located along Batang Rejang such as Kapit, Song, Kanowit and Sibu. The main objective of this paper is to develop a river model to map the extreme events for Batang Rejang. The method used in is river modelling by using InfoWorks RS software. This method is simulating the Batang Rejang in order to view the behaviours of the river in response to conditions and effects of extreme events over a given period of time. Flood maps computed from InfoWorks RS are for flood extent analysis as it provides insights to the damage for different locations at different flows. The maps are also useful for related authorities or parties to locate human activities at the catchment area and to carry out emergency flood plans in the future.
\end{abstract}

Keywords: Batang Rejang, Extreme Events, Flood

\section{INTRODUCTION}

$\mathrm{B}$ ATANG Rejang is a river in Sarawak, Malaysia. It is located in the northwest of Borneo and it originates in the Iran Mountains. The river flows approximately $563 \mathrm{~km}$ into Kapit, and then to the South China Sea, making it the longest river in Malaysia with a large network of tributaries such as Balui River, Katibas River, Ngemah River, Iran River, Pila River, Balleh River, Bangkit River and the Kanowit River. Malaysia's largest and tallest hydroelectric project, Bakun Hydro Electric Dam Project is located on the narrow Bakun Fall of Balui River.

The term flood when applied to rivers normally implies a rare event, and the magnitude of floods is often measured by return periods [1]. Extreme events mean the possibly flooding cases occur in Batang Rejang. Floods usually result from a combination of meteorological and hydrological events, such as extreme precipitations and flows [2]. In the case of Batang Rejang, man-made flooding is possible due to the high releases from upstream Bakun Dam. In this paper, flood modelling represents the basic for effective flood mitigation. Such modelling is carried out by using InfoWorks RS (River Simulation). It helps to identify the flood extents during flood events so that further analysis can be done based on the produced flood maps.

\section{RIVER MODELLING}

InfoWorks RS is a hydrodynamic model, which is capable of modelling river channels, floodplains, embankments and hydraulic structures. It simulates a river system to analyse its behaviours in different circumstances. The main inputs for the model are the river cross sections and floodplain ground data. There are 115 river cross sections available for this modelling exercise extracted from a local study [3]. Both sets of data are combined in ESRI ArcView GIS to form a Triangulation Irregular Network (TIN) terrain model (see Figure 1). In the absence of more advanced earth surface observation datasets, the available topographical data is the best at the moment. These are adequate for hydrodynamic modeling as previously proven by reports in [4]-[5]-[6].

Generally all hydrodynamic models require the input of boundary conditions. Flow data is required for the upstream end boundaries while water level data for the downstream end boundaries. These two are the most common combination to compute an essential rating curve for model routing. Hydrological data include river flows and water levels. The developed river model from Bakun Dam to Sibu Town is shown in Figure 2. It is common nowadays that hydrodynamic model ties up with geographical information system that supports flood mapping. The model calculates water levels in the river network and interpolates to points away from the network, taking account of natural barriers and available flow paths. Subtracting the

Dr Darrien Mah Yau Seng is a senior lecturer attached to the Department of Civil Engineering, Faculty of Engineering, Universiti Malaysia Sarawak. (email: ysmah@feng.unimas.my).

Nam Nguk Chiu is a graduate student attached to the Department of Civil Engineering, Faculty of Engineering, Universiti Malaysia Sarawak. (e-mail: nnchiew@hotmail.com).

Dr Frederik Josep Putuhena is a professor in water resources attached to the Department of Civil Engineering, Faculty of Engineering, Universiti Malaysia Sarawak. (e-mail: fjputuhena@feng.unimas.my).

Ir Dr Law Puong Ling is a professor in environment attached to the Department of Civil Engineering, Faculty of Engineering, Universiti Malaysia Sarawak. (e-mail: puonglaw@feng.unimas.my). 
ground elevation thus results in these points to obtain flood depths and its associated extents [7]-[8]. It would come out a basin-wide flood map in conjunction to the anticipated flood event.

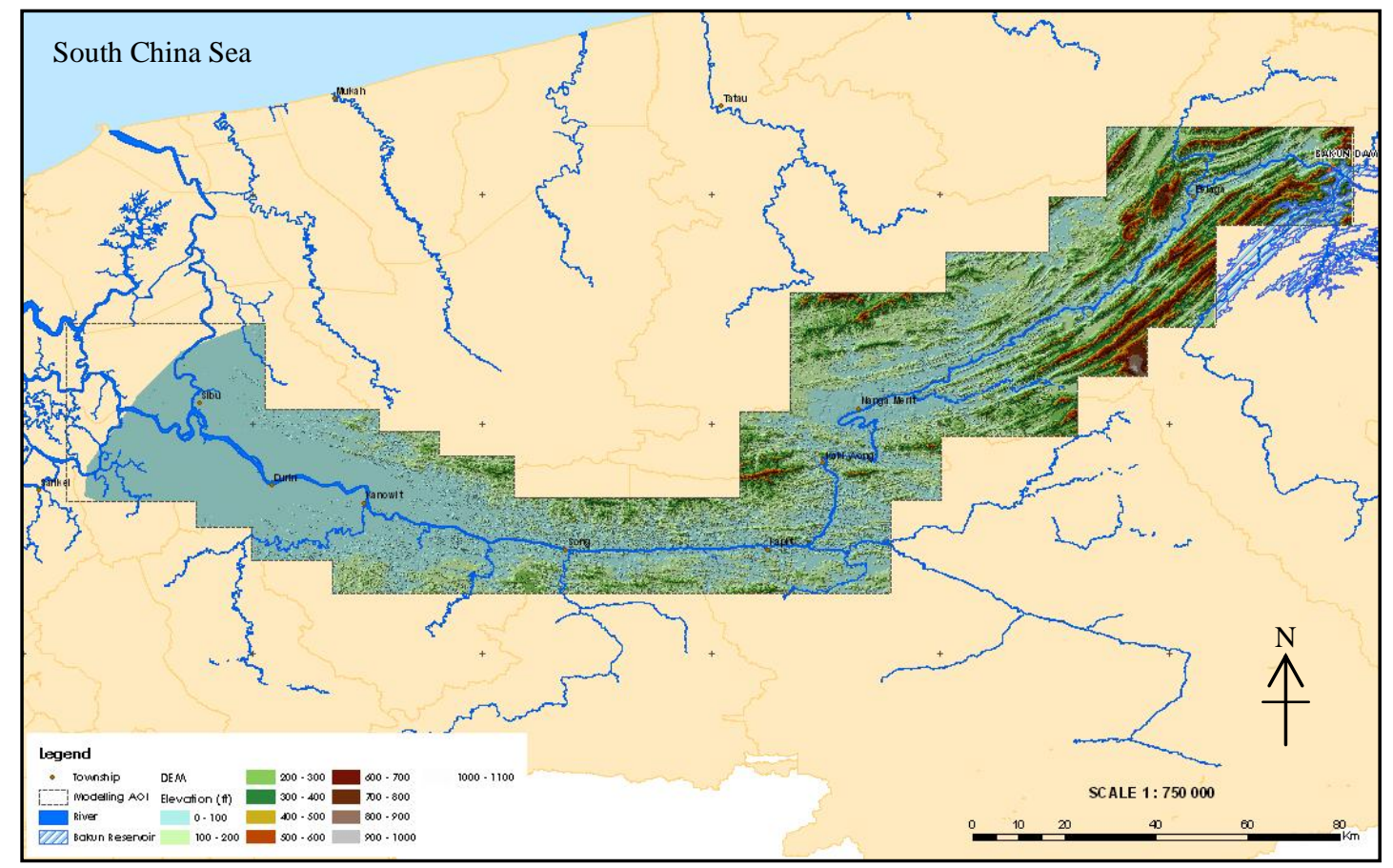

Figure 1: Terrain Model along Batang Rejang

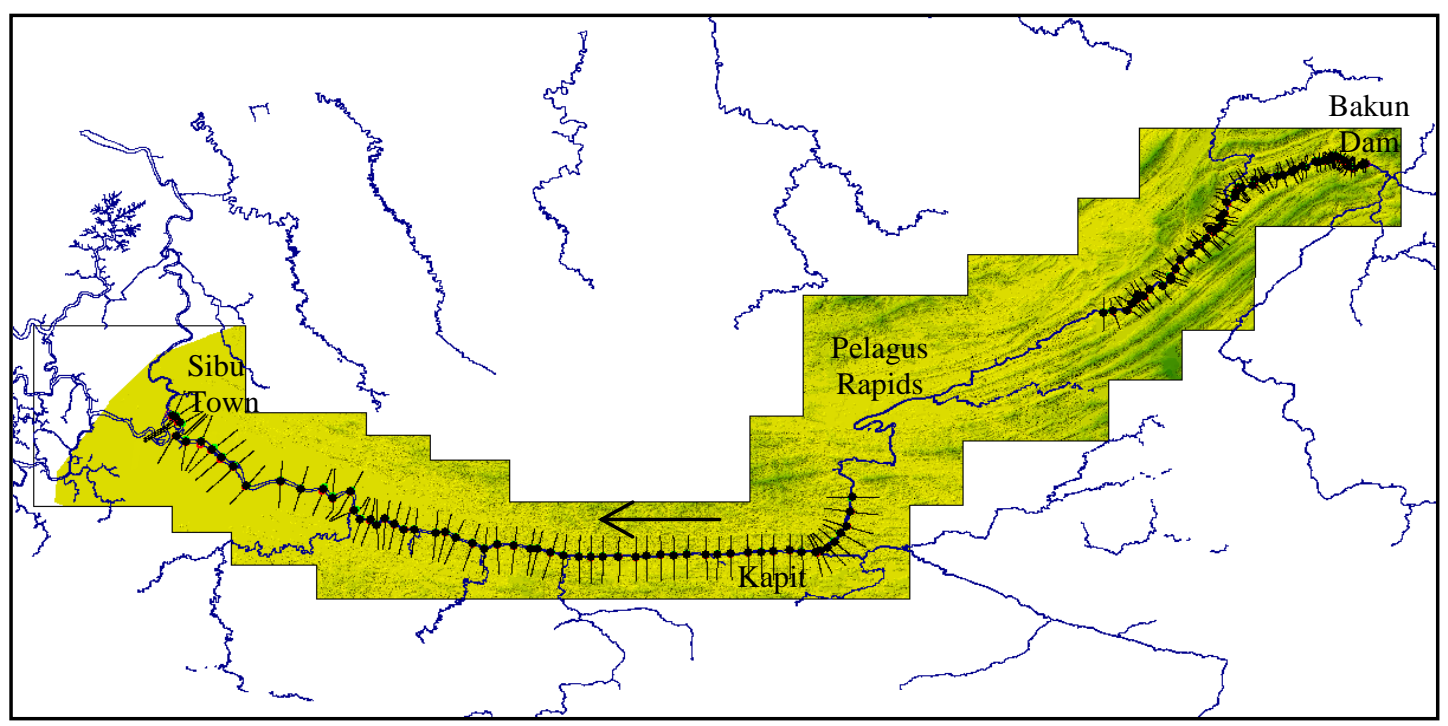

Figure 2: Batang Rejang River Network

The authors would like to point out that a stretch of Batang Rejang is without any cross sections. This river stretch is the notorious Pelagus Rapids of dangerous rough waters that the survey team in [3] was unable to reach. Because of this absence of data over about $100 \mathrm{~km}$ of river, this developed river model is crude to the extent of making efforts of model calibration a great deal of challenge. Therefore, at this stage of model development, model calibration is excluded until more data is available. Nevertheless, the river model is still useful as indicative of extreme events.

\section{RESULTS AND DISCUSSION}

The extreme events for Batang Rejang are determined followed by the flood maps at certain locations especially the significant townships along the Batang Rejang with high number of populations. These maps are overlaid on each other to produce a basin wide flood map and enable one to inspect the flood extent.

It is reported that the most probable flood (MPF) coming out of Bakun Dam was figured at $8,700 \mathrm{~m}^{3} / \mathrm{s}$ [9]. Also, the same report outlined the capacity of the spillway of Bakun Dam is capable of draining $15,000 \mathrm{~m}^{3} / \mathrm{s}$ of floodwaters. These extreme flows had been mapped in the same report. As such, any flows higher than $15,000 \mathrm{~m}^{3} / \mathrm{s}$, to the knowledge of the authors, have not been investigated. Therefore, an intension to view higher flow scenarios is simulated using the developed river 
model along the Batang Rejang. The simulations for Batang Rejang are tried for three peak flow scenarios, which are $50,000,70,000$ and $100,000 \mathrm{~m}^{3} / \mathrm{s}$. Such extreme flows are possible, considering that the volume of Bakun Reservoir may produce dam releases of such extents.

The computed flood maps give general views of the extreme behaviours of a river and its effected locations. The flood extent analysis is important for Kapit, Kanowit and Lanang Bridge near Sibu because these townships consist of high number of populations. The basin-wide flood map for Batang Rejang is shown in Figure 3. The authors would like to point out that Sibu Town is located in the low land section of Batang Rejang. The landform is alluvial plain with accumulated peat scattered around the town. The available topography data for this area is minimal, and therefore the flood maps produced are rough and underrated.

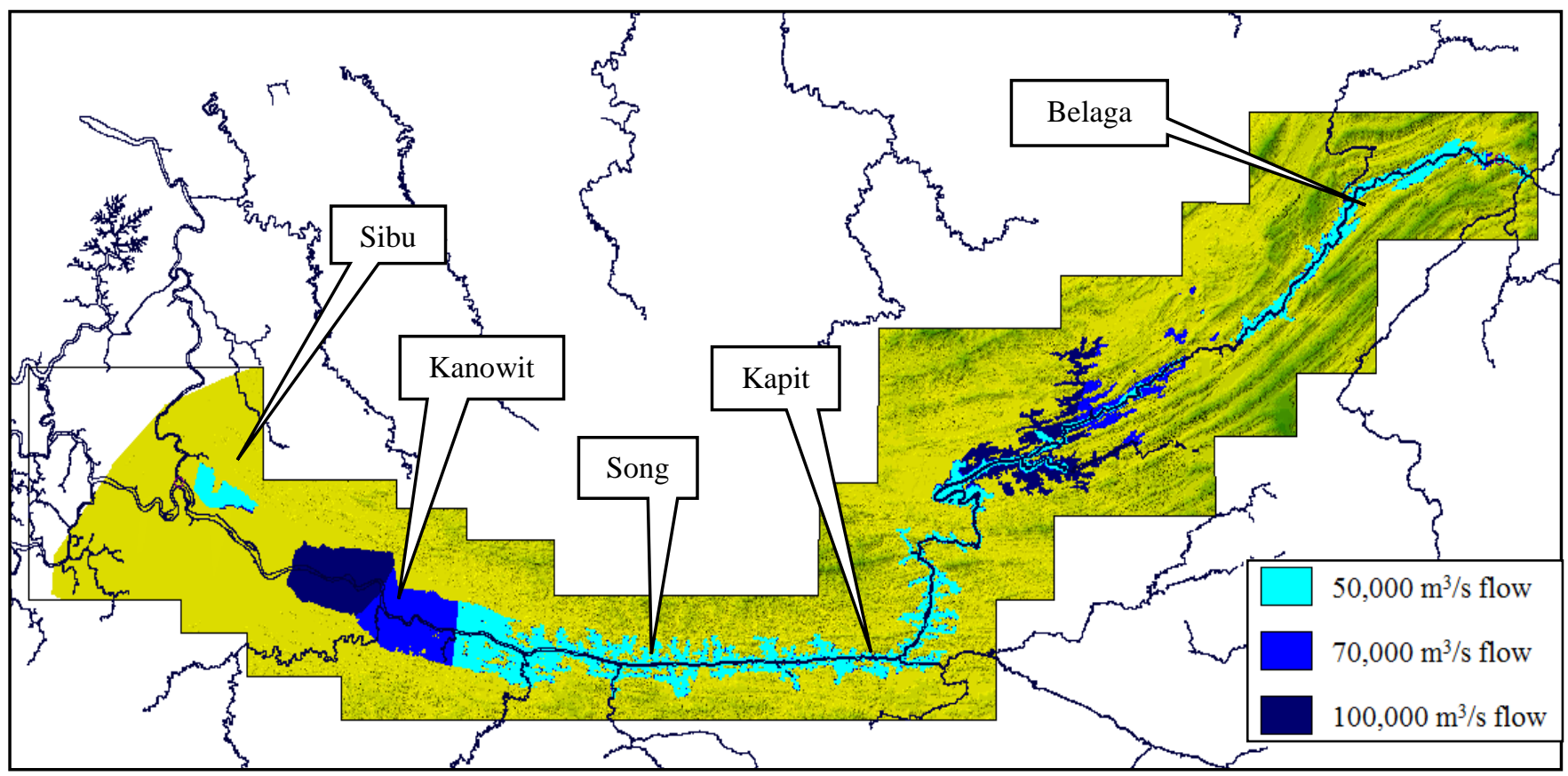

Figure 3: Basin-Wide Flood Map for Batang Rejang

Figure 4(a) shows the satellite imagery for Kapit Town extracted from Wikimapia [10]. The town is basically established on a flat plain beside the river and surrounded by high hills on both sides of banks. This explains why the flood flows of 70,000 and $100,000 \mathrm{~m}^{3} / \mathrm{s}$ are not significant in the flood map, because the floodwaters are contained within the hills. Having said so, judging from the flood extent in Figure 4(b), Kapit Town is seriously affected by the flood flows. The flooded area consists more than $50 \%$ of the overall town area of Kapit.

Figure 5(a) shows the satellite imagery of Kanowit Town. Based on the flood map of Kanowit for the same flooding scenarios shown in Figure 5(b), it is even more affected compared to Kapit Town. The flooded area is $100 \%$ of the Kanowit Town. The flood is caused by the 50,000 and $70,000 \mathrm{~m}^{3} / \mathrm{s}$ flow. In Figure $5(\mathrm{~b})$, the flood map of $50000 \mathrm{~m}^{3} / \mathrm{s}$ flow is invisible because it is toppled by layers of 70,000 and $100,000 \mathrm{~m}^{3} / \mathrm{s}$ flows to the whole Kanowit area.

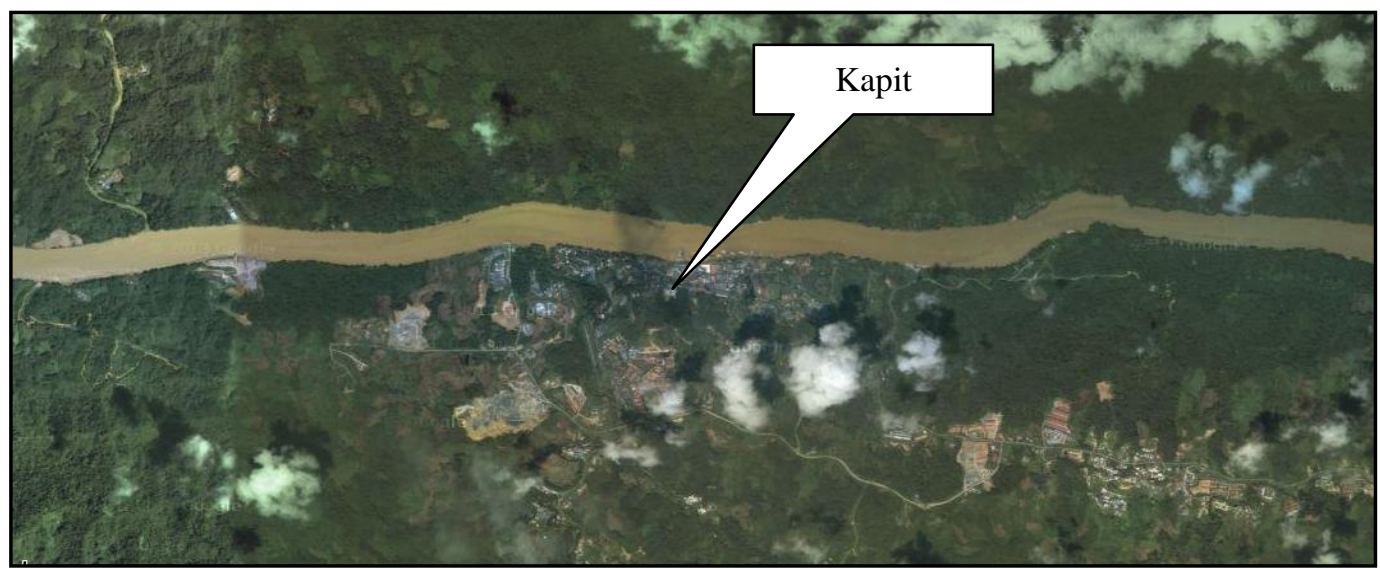

(a) Satellite Imagery 


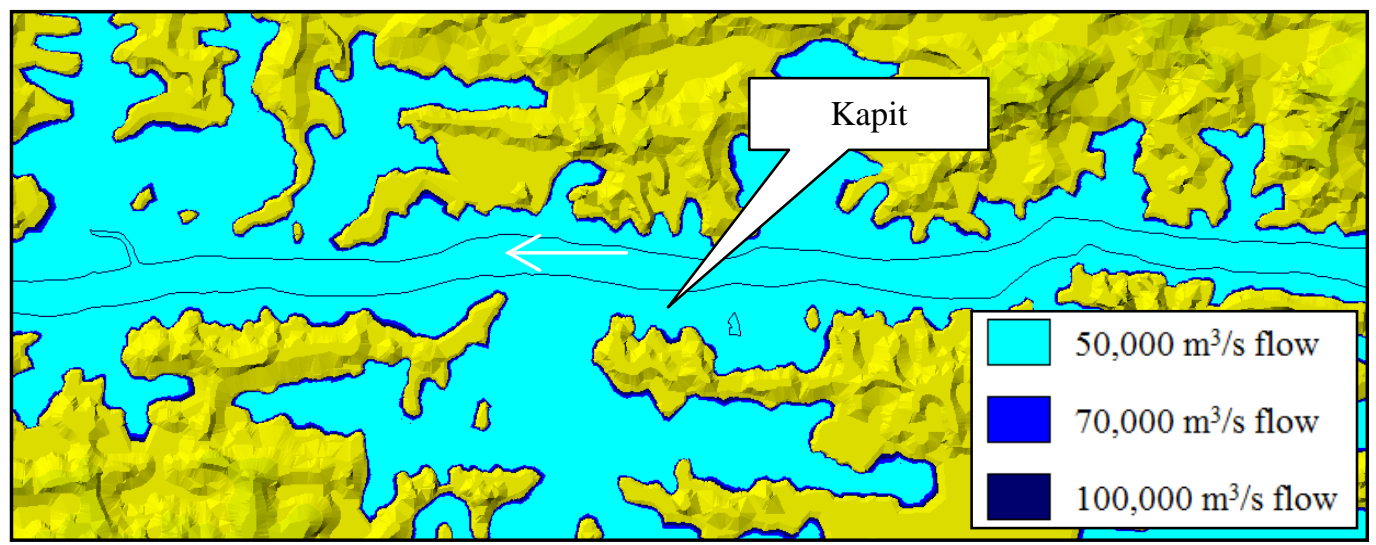

(b) Flood Extent

Figure 4: Effects of Extreme Events in Kapit, (a) Satellite Imagery and (b) Flood

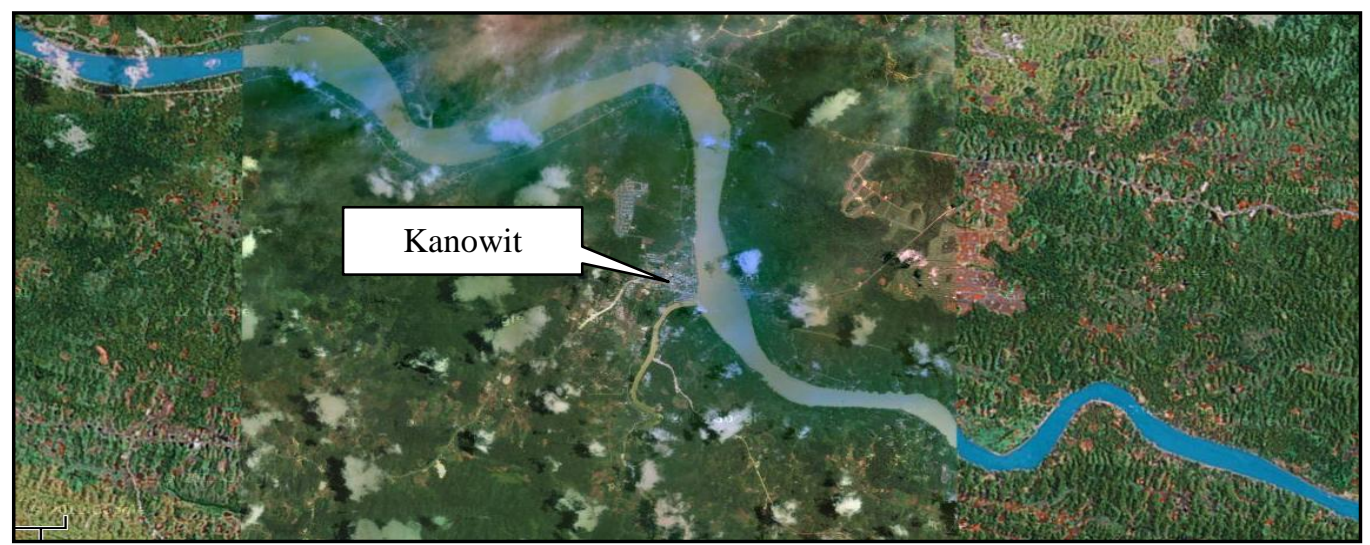

(a): Satellite Imagery

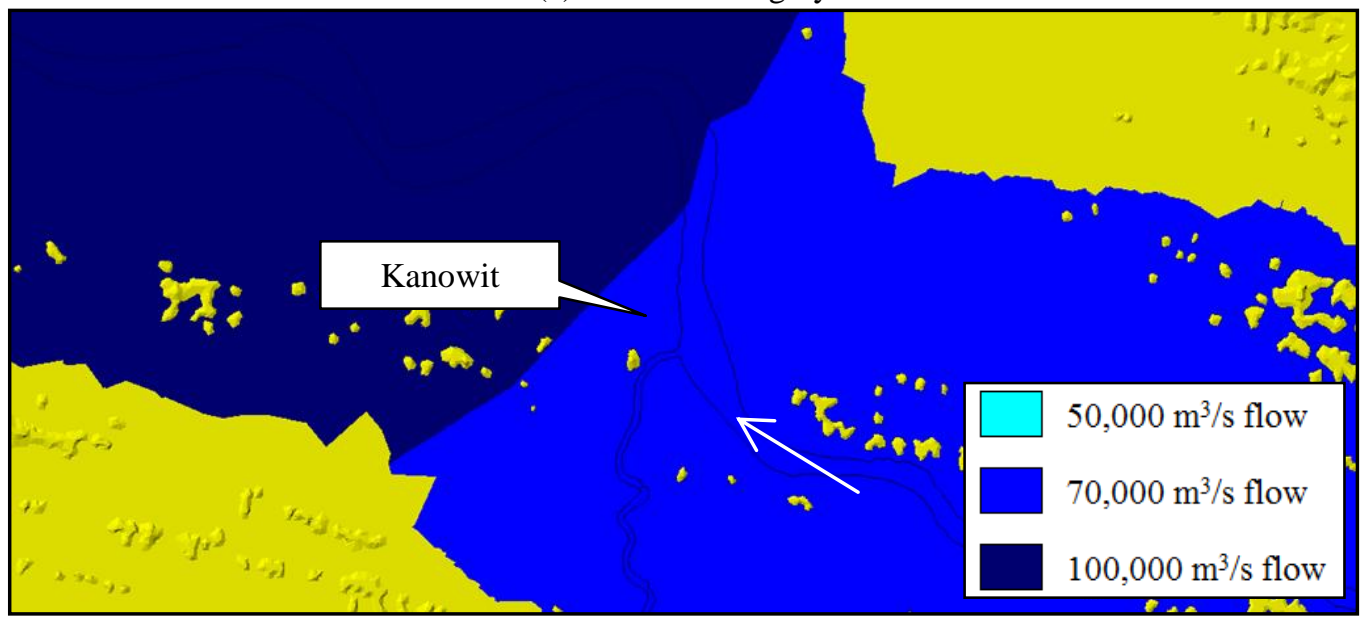

(b): Flood Extent

Figure 5: Effects of Extreme Events in Kanowit, (a) Satellite Imagery and (b) Flood Extent

\section{CONCLUSION AND RECOMMENDATIONS}

This study has demonstrated the development of a river model for Batang Rejang by using InfoWorks RS. InfoWorks RS allows users to carry out simulation to the flood model and produce the values of possible water levels. Flood simulation study could assist the local authorities or any other relevant agencies to put up a master plan with a more effective and efficient structural measures to control and minimize flood extent. Flood risk maps produced can be a quick decision support system tool to study the impact or either planned or unplanned human activities at the catchment area of a river system.

Rapid developments such as agriculture, urbanization, infrastructure development, and deforestation have contributed to severe upland soil erosions and sedimentation in the river. These situations cause changes in river system from time to time. Thus, the developed river model must be updated in future use. Currently, the government is in the process to blast seven boulders in the notorious Pelagus Rapids and it is 90\% completed on October, 2012. This alters the flow patterns along the river stretches in Pelagus area and thus affecting the river system. The river cross sections and bed level are affected and the river ground model needs to be updated for further use. 
The quality of the flood extent very much depends on the quality of the ground model. Advance technologies such as higher resolution Digital Elevation Model (DEM) could give better result on modelling instead of using the topographic maps to forecast the flood occurrence. Better illustrations such as slope, flow length and watershed boundaries can be seen obtained.

\section{ACKNOWLEDGMENT}

The authors express gratitude to opportunity, research, financial supports rendered by Universiti Malaysia Sarawak (UNIMAS). Special thanks to UNIMAS Centre of Excellence for Image Analysis and Spatial Technologies (IMAST) for producing the maps in Figures 1 and 2.

\section{REFERENCES}

[1] Ken, N. (2005). Dictionary of Water Engineering. ITDG Publishing.

[2] Abhas., K. J., Robin., B., and Jessica., L. (2011). Cities and Flooding: A Guide to Integrated Urban Flood Risk Management for the 21st Century. Washington: The World Bank.

[3] Sarawak Energy Berhad (SEB). (2012). Emergency Response Plan for Murum Dam.

[4] Néelz, S., Pender, G., Villanueva, I., Wilson, M., Wright, N.G., Bates, P., Mason, D., and Whitlow, C. (2006). Using remotely sensed data to support flood modelling. Proceedings of the Institution of Civil Engineers - Water Management, 159 (1), pp. 35-43.

[5] Pender, G., and Néelz, S. (2007). Use of computer models of flood inundation to facilitate communication in flood risk management. Environmental Hazards, 7 (2), pp. 106-114.

[6] Devesa, F., Comas, J., Turon, C., Freixó, A., Carrasco, F., and Poch, M. (2009). Scenario analysis for the role of sanitation infrastructures in integrated urban wastewater management. Environmental Modelling \& Software, 24 (3) March, pp. 371-380.

[7] Mah, D.Y.S., and Selaman, O.S. (2012). Sarawak River Barrages and Environmental Quality. A research monograph published by Penerbit Universiti Malaysia Sarawak, Kota Samarahan, Sarawak, Malaysia.

[8] Mah, D.Y.S., Putuhena, F.J., and Lai, S.H. (2011). Modelling the flood vulnerability of deltaic Kuching City, Malaysia. Natural Hazards, 58 (3), pp. $865-875$.

[9] Sarawak Hidro. (2003). Emergency Response Plan for Bakun Dam.

[10] Satellite imageries for locations along Batang Rejang extracted from www.wikimapia.org, a site copyrighted by Google. 